Int. J. Dev. Biol. 53: 483-491 (2009)

doi: $10.1387 / \mathrm{ijdb} .082801 \mathrm{hk}$

\title{
Gonad-stimulating substance-like molecule from the radial nerve of the sea cucumber
}

\author{
HIDEKI KATOW ${ }^{*}, 1$, TOMOKO KATOW ${ }^{1}$ and AKIHIKO MORIYAMA ${ }^{2}$ \\ ${ }^{1}$ Research Center for Marine Biology, Tohoku University, Asamushi, Aomori, Japan and \\ ${ }^{2}$ Division of Biomolecular Science, Institute of Natural Sciences, Nagoya City University, Nagoya, Aichi, Japan
}

\begin{abstract}
Gonad-stimulating substance-like molecule (GSSL) was isolated from the radial nerve of the sea cucumber, Apostichopus japonicus (Aj-GSSL), and its partial DNA and protein sequences were characterized. The smaller part of the molecule that also retains GSSL activity was estimated. Radial nerve extract (RNE) induced germinal vesicle breakdown (GVBD) at $3 \mathrm{mg} / \mathrm{ml}$ in $85 \%$ of immature ovarian oocytes. Similar intensity of GSSL activity to RNE was seen in a fraction that contained peptides between $3 \mathrm{kDa}$ and $10 \mathrm{kDa}$ (3-10 kDa-fraction) separated by ultrafiltlation membrane. MALDI-TOF MS analysis and silver-stained 18\% SDS-PAGE slab gels identified a major peptide at around 4.6 kDa in a 3-10 kDa-fraction, and that was subjected to internal protein sequencing. The resulting 12-amino acid sequence was not found in the BLAST database to date. Immunohistochemistry using antiserum raised against the 12-amino acid peptide located the peptide to granular cells in the hyponeural part of the radial nerve and in the epineural sinus beneath the radial nerve. Sequence data was obtained using degenerate primers designed from the 12-amino acid sequence and 5' and 3' RACEs. These resulted in a 148 bp cDNA that coded a 43amino acid sequence of $\mathrm{H}_{2} \mathrm{~N}$-VLSKQAHHHHHEGWSLPGVPAEIDDLAGNIDYNIFKEQREKIK-COOH. The synthetic 43-amino acid Aj-GSSL generated from this sequence induced GVBD in $50 \%$ of immature ovarian oocytes at $6 \mu \mathrm{M}$. An $\mathrm{N}$-terminal 21-amino acid peptide of the synthetic partial Aj-GSSL (Aj-GSSL-P1) induced GVBD to $80 \%$ of immature ovarian oocytes at $12 \mu \mathrm{M}$. This indicated that Aj-GSSL-P1 is of sufficient length for GSSL activity.
\end{abstract}

KEY WORDS: DNA structure, protein structure, functional structure, oocyte maturation

\section{Introduction}

The exploration of nervous system in the echinoderm larvae and adult made great strides during past decade in sea urchins (e. g. Beer et al., 2001; Sly et al., 2002;Yaguchi and Katow, 2003; Katow et al., 2004; Nakajima et al., 2004; Burke et al., 2006; Katow et al., 2007; Katow, 2008), starfishes (e.g. Elphick et al., 1995; Byrne et al., 2005), sea cucumbers (e.g. Garcia-Arraras et al., 1991; Diaz-Miranda et al., 1995; Inoue et al., 2002; Byrne et al., 2006: Diaz-Balzac et al., 2007; Bishop and Burke, 2007), and brittle stars (de Bremaeker et al., 1997; Hirokawa et al., 2008), mainly by introducing immunochemistry using antibodies raised against various neurotransmitters or anti-synaptotagmin monoclonal antibody, and molecular biology.

The function of the echinoderm nervous systems, however, remains obscure, except a few reports, such as relaxation of cardiac stomach preparation by SALMFamide (Elphic et al., 1995), inhibiting gonad-stimulating substance secretion by SALMFamide in starfish (Mita et al., 2004), and controlling larval swimming by the serotonergic nervous system in sea urchin larvae (Yaguchi and Katow, 2003; Katow et al., 2007).

The presence of neurohormone system could be widely distributed in the echinoderm. Studies on neurohumoral regulation have made great progress in asteroids. In particular GSS present in the radial nerve extract has been a focus of research. In starfishes (Kanatani, 1967; Strathmann and Sato, 1969) and sea cucumbers (Maruyama, 1985) the oocyte maturation is initiated by GSS secreted from the radial nerve. Although the GSS signal

Abbreviations used in this paper: GVBD, germinal vesicle breakdown; GSSL, gonad-stimulating substance like; RNE, radial nerve extract.

\footnotetext{
*Address correspondence to: Dr. Hideki Katow. Research Center for Marine Biology, Tohoku University, Asamushi, Aomori, Aomori, Japan $039-3501$. Tel. and Fax: 81-17-752-3390. e-mail: hkatow@m.tains.tohoku.ac.jp 
transduction pathway has been extensively studied in starfish (e.g. Kanatani et al., 1971; Mita et al., 2007), little is known in sea cucumbers.

It has been suggested that the sea cucumber GSS is a small peptide of around a few kilo Daltons (Maruyama, 1985), which is similar molecular size to that of sea urchin (Cochran and Engelmann, 1976), and of starfish (Yoshikuni, 2006; Mita et al., 2007). However, in sea cucumbers the radial nerve extract (RNE) that contains GSS active factor from different species are not always work equally beyond species difference (Maruyama, 1985). This suggests that molecular structure of GSS will differ among echinoderms. In this study we aimed (1) to isolate a peptide factor involved in the induction of germinal vesicle breakdown (GVBD) in immature oocytes in fecund ovarian tubes of the sea cucumber Apostichopus japonicus, (2) to specify the molecular structure through the sequencing of DNA and peptide, (3) to elucidate the presence of any "functional domain" that may represent its function with much smaller structure, and (4) to locate its immunohistological sites in the radial nerve that potentially consequences the discovery of the GSS-ergic nervous system by raising specific antibodies that has never been reported in echinoderm.

In this study we have isolated and sequenced DNA and amino acid of a 43-amino acid peptide factor that induces GVBD in immature ovarian oocytes. Its function was retained in a shorter 21-amino acid peptide, indicating the presence of a functional domain. An antiserum was generated against a part of the peptide. The antigen peptide was immunohistologically detected at the hyponeural part of the radial nerve and the epineural sinus beneath the radial nerve. The antigen peptide was detected also in the fibers around the radial nerve, suggesting the presence of the peptidergic nervous system.

This work is associated with a Japanese Patent Application (No.2008-5430) filed on January 15, 2008.

\section{Results}

\section{Fractionation of radial nerve extract (RNE) used for isolating a peptide factor}

The RNE induced GVBD in $85 \%$ of 264 immature ovarian oocytes (immature oocytes) shed from ovary in 2 hours at $3 \mathrm{mg} / \mathrm{ml}$ (Fig.1A, D). Similar GVBD induction ratio (80\% in 244 immature oocytes) was achieved by $3 \mathrm{mg} / \mathrm{ml}$ of 3-10 kDa-fraction (Fig.1B,
D). At $300 \mu \mathrm{g} / \mathrm{ml}$, however, neither RNE (about 6\% in 190 immature oocytes) nor 3-10 kDa-fraction (about $8 \%$ in 66 immature oocytes) significantly induced GVBD (Fig.1D). The peptides smaller than $3 \mathrm{kDa}$ induced little GVBD at $3 \mathrm{mg} / \mathrm{ml}$ (about $15 \%$ in 94 immature oocytes, Fig.1C, D), and a little better than that at $300 \mu \mathrm{g} / \mathrm{ml}$ (39\% in 205 immature oocytes) (Fig.1D). Thus, the 3$10 \mathrm{kDa}$ fractions were used for isolating a peptide factor that induces GVBD in immature oocytes in fecund ovarian tubes. The peptides smaller than $3 \mathrm{kDa}$ did not induce GVBD, and so were excluded from the further analysis.

\section{Isolation of GVBD induction active peptide}

The 3-10 kDa fraction was analyzed under a Matrix Assisted Laser Desorption Ionization Time-of-flight Mass Spectrometry (MALDI-TOF MS). This resulted in visualization of large number of peptides of less than $3 \mathrm{kDa}$ and a few larger molecules (Fig.2A, double-headed arrow). Among the molecules larger than $3 \mathrm{kDa}$, a prominent peak was obtained at about $4.6 \mathrm{kDa}$ region (Fig.2A, arrow). No peak larger than $4.6 \mathrm{kDa}$ was found.

Then 4.6 kDa molecule was separated from 3-10 kDa-fraction by the sodium dodecyl sulfate polyacrylamide gel electrophoresis (SDS-PAGE). According to silver stain of the slab gels, two major bands were seen (Fig.2B). Since the smaller band at approximately $4.8 \mathrm{kDa}$ region (Fig. $2 \mathrm{~B}$, arrow), on the other hand, was seen also by the present MALDI-TOF MS analysis (Fig.2A), this band was regarded to be a major peak seen at $4.6 \mathrm{kDa}$ region by MALDI-TOF MS analysis.

\section{8 kDa peptide sequencing}

To estimate the internal amino acid sequence of the $4.8 \mathrm{kDa}$ band, the band was dissected from the slab gels, and subjected to HPLC analysis after digestion with trypsin. A fraction was chosen for the internal amino acid sequencing, because only one peak was in that fraction (Fig2C, arrow). According to 12-cycle Edmond degradation analysis, an amino acid sequence of $\mathrm{NH}_{2}$ AEIDDLAGNIDY-COOH was predicted. This amino acid sequence (12-amino acid peptide) was not listed in the BLAST protein database, and was also different from starfish GSS (Mita et al., 2007). This suggests the novelty of the peptide. Since the $4.8 \mathrm{kDa}$ peptide is a component of RNE prepared from a mixture of tissues around the radial nerve, and was chosen based on its relative molecular mass, its exact histological localization by
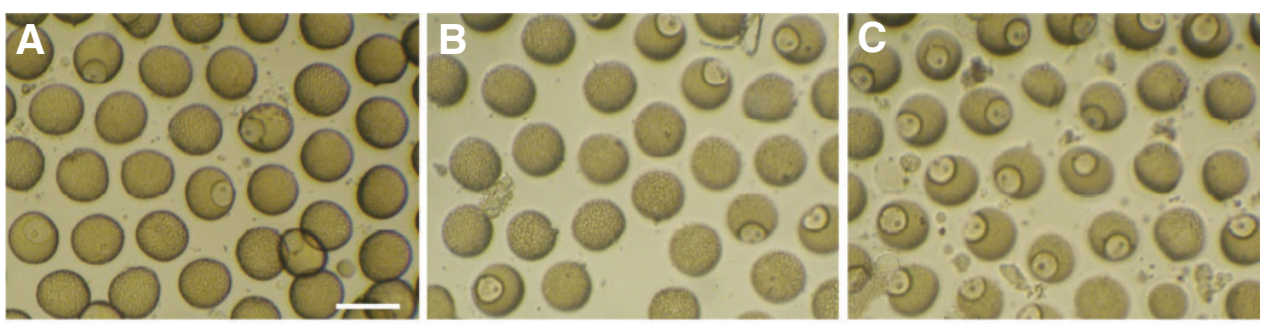

Fig. 1. Germinal vesicle breakdown (GVBD) induction by radial nerve extract (RNE) and its subfractions. GVBD after application of $3 \mathrm{mg} / \mathrm{ml}$ of 3-10 $\mathrm{kDa}$-fraction of $R N E$ (A), $3 \mathrm{mg} / \mathrm{ml}$ of RNE at 3$10 \mathrm{kDa}$-fraction (B), and $300 \mu \mathrm{g} / \mathrm{ml}$ of $3 \mathrm{kDa}>$-fraction of RNE that left many immature oocytes (C). (D) GVBD ratios by $R N E$, 3-10 $\mathrm{kDa}$-fraction $(3-10 \mathrm{kDa})$, and a fraction smaller than $3 \mathrm{kDa}(3 \mathrm{kDa})$. The number of immature oocytes examined at $3 \mathrm{mg} / \mathrm{ml}$ of RNE, 3-10 $\mathrm{kDa}$-fraction, and $3 \mathrm{kDa}>$-fraction were 264, 244 and 94, respectively, and those at $300 \mu \mathrm{g} / \mathrm{m} /$ were 190, 66, and 205, respectively. Vertical

\section{D}

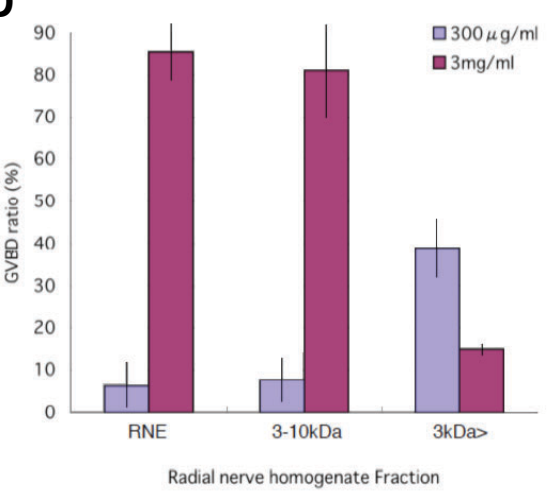

bars show standard deviations. Bar in (A): $200 \mu \mathrm{m}$. 


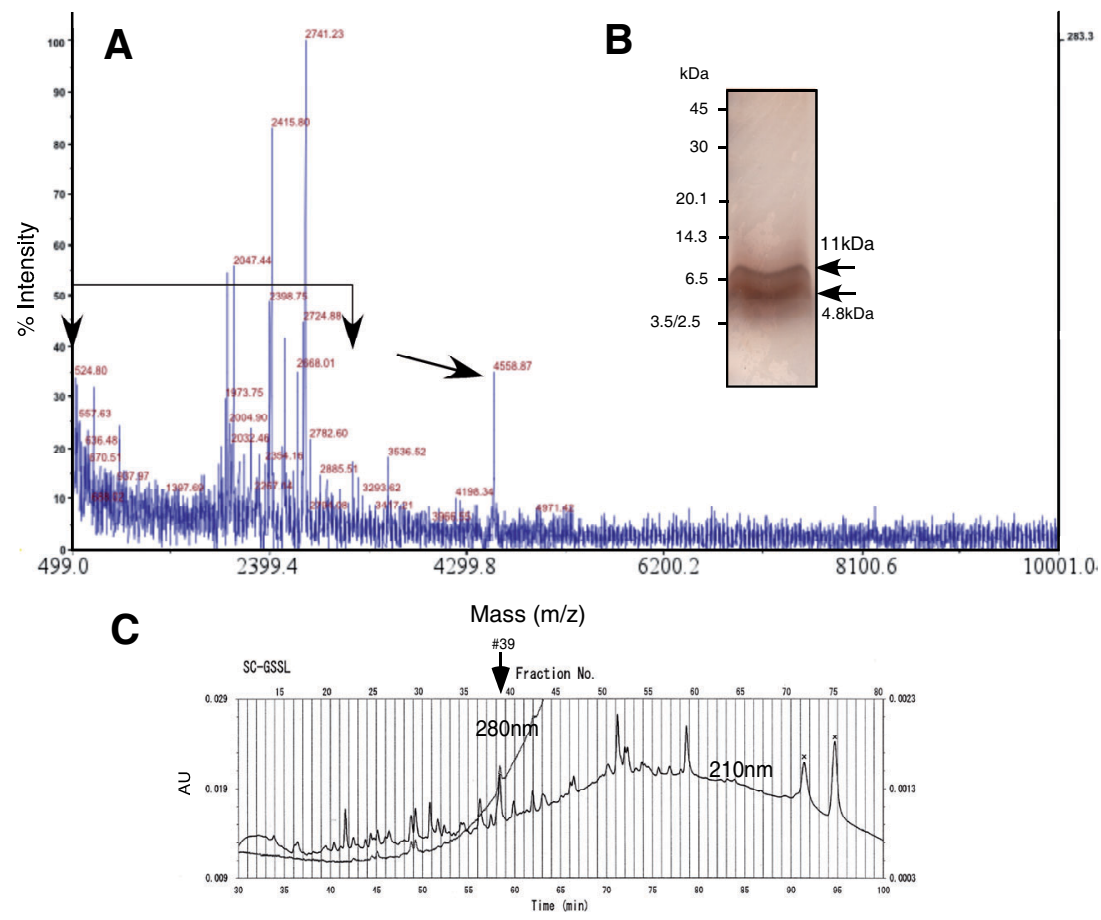

Fig. 2. Molecular analysis of 3-10 kDa-fraction. (A) MALDI-TOF mass spectrum showed a distinctive single peak at 4,558.87 Dalton (arrow). M/z range 499-10001 MALDI matrix: Double-headed arrow shows a range smaller than $3 \mathrm{kDa}$. (B) SDS-PAGE slab gel of 3-10 kDafraction showed two MS-silver stained bands at $4.8 \mathrm{kDa}$ region and $11 \mathrm{kDa}$ region. (C) HPLC analysis of 3-10 kDafraction of radial nerve extract. Fraction \#39 (arrow) was used for internal protein sequencing.

epineural sinus, indicating the present antigen was present in the radial nerve (Fig.3A). It was rarely detected in the ectoneural part of the radial nerve (Fig.3A). The 12-amino acid peptide was also detected in the cells with granules in non-neural tissue (Fig.3B). However, under the presence of $3 \mathrm{mg} / \mathrm{ml}$ antigen peptide, the antiserum did not bind to the granules (Fig.3C), indicating the antiserum bound specifically to the 12-amino acid peptide in the granules of the radial nerve. With immunoblotting, the antiserum bound to a band at approximately $170 \mathrm{kDa}$ region (Fig.3D, lane 1). This was also not detected under the presence of $1 \mathrm{mg} / \mathrm{ml}$ of antigen peptide (Fig.3D, lane 2), indicating that the antiserum bound specifically to the 12-amino acid peptide in $170 \mathrm{kDa}$ band region. The relative molecular mass at that region, however, was significantly larger than the one that we have initially isolated. This apparent discrepancy may suggest that the $4.8 \mathrm{kDa}$ peptide is a component of a larger 170 $\mathrm{kDa}$ protein. The small product may have been isolated due to partial proteolysis or heating associate with isolation of starfish GSS (Kanatani et al., 1971).

The granules that contain the antigen peptide were comprised of clusters of smaller granules of $6-7 \mu \mathrm{m}$ in diameter on average

Fig. 3. Immunochemical analysis of radial nerve extract. (A) Immunohistochemical location of the antigen peptide in radial nerve by confocal laser scanning microscopy. Immunohistochemically antigen peptide was located in the granules of 20-30 $\mu \mathrm{m}$ diameter at the hyponeural part (hnp) of the radial nerve and in the epineural sinus (es). Such granules were not seen in the ectoneural part (enp) of the radial nerve. The radial nerve was split to two parts at the middle during sample preparation. Arrow shows a branch of nerve fiber extending from the hyponeural part of the radial nerve towards the circular muscle. hs: hyponeural sinus. Imbw: longitudinal muscles of the body wall. ctbw: connective tissue of the body wall. (B) Confocal laser scanning microscopy of Polywax section around the radial nerve. Antigen peptide containing granules (AP granule) around the radial nerve. (C) The nearby Polywax section of (B) incubated with antiserum and $3 \mathrm{mg} / \mathrm{ml}$ of antigen peptide. Immunoreaction of AP granules decreased considerably. (D) Immunoblotting shows a single band at $170 \mathrm{kDa}$ region (lane 1), whereas under the presence of $1 \mathrm{mg} / \mathrm{ml}$ antigen peptide, the band was not detected (lane 2). (E) The antiserum bound to the granules that comprised of smaller 6-7 $\mu$ m diameter granules. (F) The antiserum also bound to 1-2 $\mu \mathrm{m}$ diameter fibers that extended to the tissues around the radial nerve. (G) Two antiserum-binding
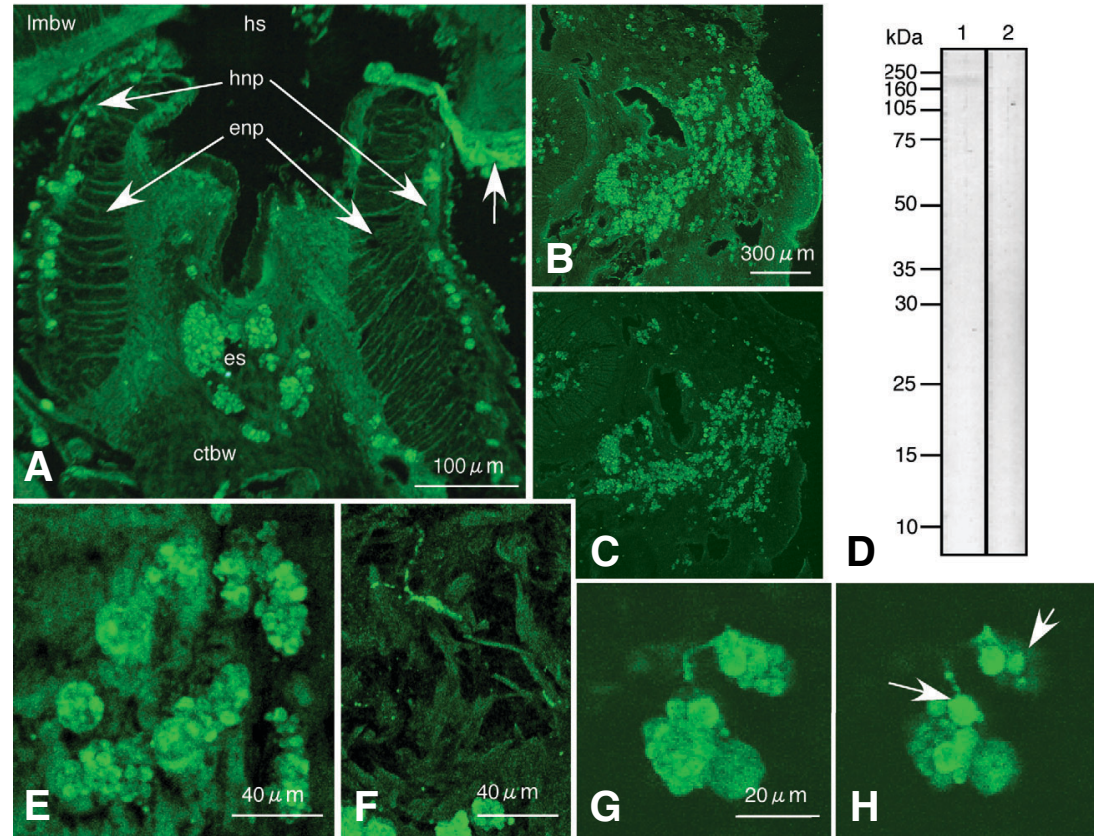

features were connected. (H) Optical section of $1 \mu \mathrm{m}$ thick separated from (G) showed structural connection between 1-2 $\mu$ m diameter fibers and 6$7 \mu \mathrm{m}$ diameter smaller granules. Bars in $(A, B, E, F, G): 100 \mu \mathrm{m}, 300 \mu \mathrm{m}, 40 \mu \mathrm{m}, 40 \mu \mathrm{m}$, and $20 \mu \mathrm{m}$, respectively. 

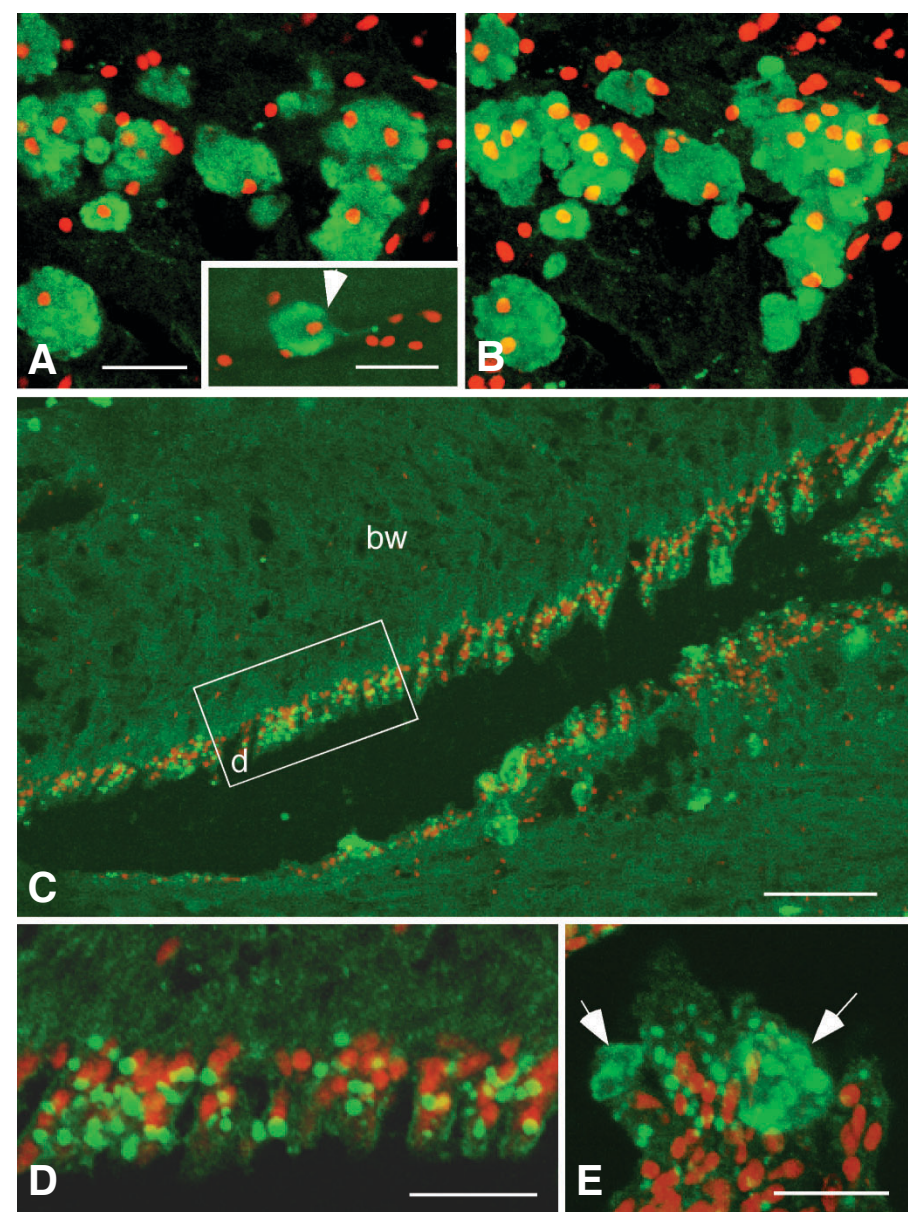

Fig. 4. Confocal microscopy of double-stained immunohistochemistry of antigen peptide containing granules (AP granule). (A) One micrometer thick optical section image of 20-30 $\mu$ m diameter AP granules (green) shows a few nuclei (red) in each cluster of granules, indicating they are the cells with large size (granular cell). Some of the granular cells extended 1-2 $\mu$ m diameter cellular process (inset, arrow). Inset is stacked image of two $1 \mu \mathrm{m}$-thick optical sections. (B) Stacked $14 \mu \mathrm{m}$ thick image of the same group of cells as shown with $(A)$ revealed multiple nuclei in each of granular cell. (C) AP granules were also seen along the apical surface of the coelomic epithelium. (D) Stacked $3 \mu$ m-thick image of the coelomic epithelium. These granules were small, and attained 1.5-3 $\mu \mathrm{m}$ in diameter in the cytoplasm of the epithelial cells. (E) Stacked $3 \mu \mathrm{m}$-thick image of AP granules near the apical surface of the coelomic epithelium. Occasionally granular cells with ruptured plasma membrane were seen associated with 1.5-3 $\mu \mathrm{m}$ diameter granules (arrows). Rectangle in (C) shows location of (D). bw: body wall. Bars in $(A)$, (inset of $A$ ), $(C)$, and (D): $20 \mu \mathrm{m}$, and in (B): $60 \mu \mathrm{m}$.

(Fig3E). Other than these granules, fine fibers of approximately 1$2 \mu \mathrm{m}$ in diameter also were seen with distinctive immunoreaction in the tissues surrounding the radial nerve (Fig.3F). According to the optical section-to-section analysis of the confocal microscopy, it was found that these fibers connected to the 6-7 $\mu \mathrm{m}$ diameter granules in the 20-30 $\mu \mathrm{m}$ granules (Fig.3G, H, arrows), suggesting structural connection between the 1-2 $\mu \mathrm{m}$ diameter fibers and $20-30 \mu \mathrm{m}$ clusters of the antigen peptide-containing granules (AP granules). Confocal microscopy of double stained immunohistochemistry with the antiserum and propidium iodide of $1 \mu \mathrm{m}$ thick optical sections showed the presence of one or more nuclei in the 20-30 $\mu \mathrm{m}$ diameter clusters of AP granules (Fig.4A), indicating the AP granules are sub-cellular component of 20$30 \mu \mathrm{m}$ diameter cells (granular cell). A few micrometers diameter antiserum-positive fiber was protruded from some of the granular cells (Fig.4A, inset). Stacked image of the same AP granules as Fig.4A showed multiple nuclei in the granular cells, indicating they are clusters of the granular cells (Fig.4B). The smaller diameter antiserum-positive granules lined along the apical surface of the coelomic epithelium (Fig.4C, D). Some of these smaller diameter granules were associated with the granular cells with fragmented cell surface (Fig. 4E, arrows), suggesting the occurrence of holocrine type secretion of AP granules at the apical region of the coelomic epithelium.

\section{Gene and protein structures of $4.8 \mathrm{kDa}$ peptide}

The cDNA of the $4.8 \mathrm{kDa}$ peptide comprised of $148 \mathrm{bp}$ of DNA sequence that included $129 \mathrm{bp}$ of partial open reading frame and a stop codon that was followed by $16 \mathrm{bp}$ of poly (A) (Fig.5A, the DNA Data Bank of Japan, AB434762). The open reading frame thus encoded 43 amino acids of theoretical relative molecular mass (MrT) of 4,958.53 Daltons according to ExPASy Compute $\mathrm{pl} / \mathrm{MW}$ tool (http://us.expasy.org/tools/pi_tool.html). According to the NCBI Protein BLAST search, the present 43-amino acid sequence is unique, and no similar protein was blasted. According to proteolytic sites estimation by ExPASy, PeptideCutter, using 18 proteinases described in Materials and Methods, the 4.8 $\mathrm{kDa}$ peptide can be divided to two regions; a 17 -amino acid $\mathrm{N}$ terminal half and a 26 -amino acid C-terminal half between Pro ${ }^{17}$ and Gly $^{18}$ that are not the target of any of the 18 proteinases. There were 16 amino acids that are potential targets of more than 2 proteinases in synthetic $4.8 \mathrm{kDa}$ peptide, including 4 trypsin target sites, $\mathrm{K}^{3}, \mathrm{~K}^{36}, \mathrm{R}^{39}$, and $\mathrm{K}^{41}$ (Fig.5A). Three out of these four amino acids located in the $\mathrm{C}$-terminal half. The $\mathrm{N}$-terminal half was comprised of 4 target sites of more than 2 proteinases, whereas the C-terminal half contained three times more target sites of proteinases (Fig.5B), suggesting that the C-terminal half is more vulnerable to proteolysis than the $\mathrm{N}$-terminal half.

Although according to ExPASy Database of protein domains, families and functional sites (http://www.expasy.ch/prosite/), the $4.8 \mathrm{kDa}$ peptide did not contain known intra-domain structure, it contained characteristic basic 5 -histidine sequence ( $\mathrm{His}^{7}-\mathrm{His}^{11}$ ) that is also contained in many known proteins such as, Regulator of $G$ protein signaling protein 7 of Caenorhabditis elegans (accession number ACA53538) and CBX4 protein of human (accession number ACA49234). Biological role or structural significance of the five-histidine sequence, however, is not yet elucidated.

\section{GVBD breakdown inducing activity of synthetic $4.8 \mathrm{kDa}$ peptide and its minimum active structure}

To examine whether the 43-amino acid peptide has GVBD inducing activity comparable to RNE, immature oocytes shed from ovaries dissected at $1 \mathrm{~cm}$ long were incubated with the 43amino acid peptide at $3 \mu \mathrm{g} / \mathrm{ml}, 30 \mu \mathrm{g} / \mathrm{ml}$ and $50 \mu \mathrm{g} / \mathrm{ml}$, respectively, for 4 hours of incubation period. Among three different concentrations of the 43 -amino acid peptide, $30 \mu \mathrm{g} / \mathrm{ml}$ of the peptide $(6 \mu \mathrm{M})$ induced GVBD in approximately $50 \%$ of 822 immature oocytes (Fig.6), whereas at lower (approximately in $25 \%$ of 730 immature oocytes) or higher (approximately in $20 \%$ of 841 immature oo- 
cytes) than that concentration of the 43-amino acid peptide did not induce GVBD as effectively as that at $30 \mu \mathrm{g} / \mathrm{ml}$. The difference of effectiveness became prominent at and after 2 hours of incubation period. Thus, the 43-amino acid peptide has significant activity to induce GVBD (Aj-GSSL).

The biologically active proteins or peptides do not always require the full-length of their amino acid sequence to function. To examine whether GSSL activity can be represented by shorter peptide, the amino acid sequence of the Aj-GSSL peptide was split to three different shorter sequences (Fig.7A). Aj-GSSL-P1 peptide ( $M r T=2,324.59$ Dalton) was comprised of 21 amino acids sequence of $\mathrm{N}$-terminal half $\left(\mathrm{V}^{1}-\mathrm{A}^{21}\right), \mathrm{Aj}$-GSSL-P2 (MrT=2,216.39 Dalton) was of 21 amino acids of the middle of the 43-amino acid peptide $\left(\mathrm{G}^{12}-\mathrm{N}^{33}\right)$, and Aj-GSSL-P3 (MrT=2,625.96 Dalton) of 22 amino acids of the $\mathrm{C}$-terminal half $\left(\mathrm{E}^{22}-\mathrm{K}^{43}\right)$ (Fig.7A). These synthetic peptides that were most effective in induction of GVBD were dissolved in FSW at $30 \mu \mathrm{g} / \mathrm{ml}$. After 3 hours of incubation, AjGSSL-P1 induced GVBD in approximately $80 \%$ of 2,081 immature oocytes (Fig.7B). To reach GVBD to $50 \%$ of immature oocytes Aj-GSSL-P1 peptide took 1 hour, whereas the 43-amino acid Aj-GSSL took 3 hours. Thus, Aj-GSSL-P1 at $30 \mu \mathrm{g} / \mathrm{ml}(12 \mu \mathrm{M})$ more effectively induced GVBD than the 43-amino acid Aj-GSSL. Although Aj-GSSL-P2 and -P3 also induced the GVBD in approxi-
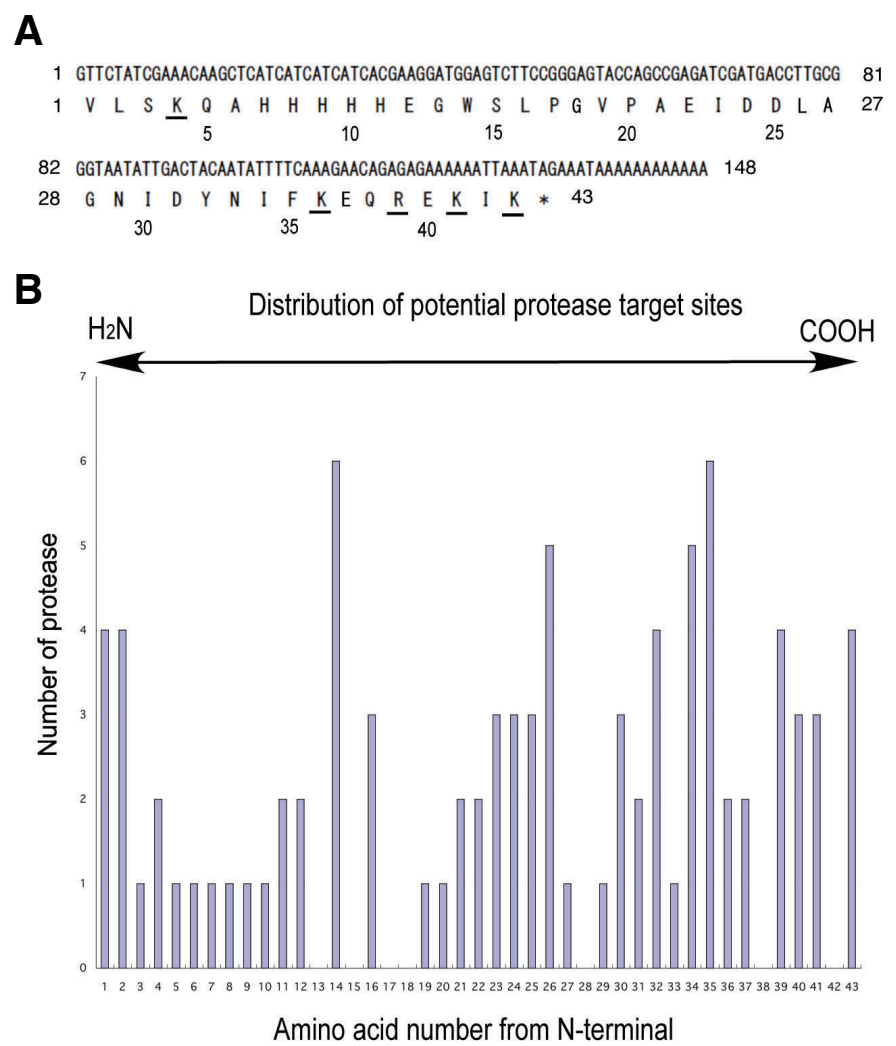

mately $35 \%$ of 1,682 immature oocytes and in approximately $28 \%$ of 2,073 immature oocytes, respectively, their activity was considerably lower than that of Aj-GSSL-P1. Plain FSW induced little GVBD (in approximately $5 \%$ of 1,733 immature oocytes in 3 hours of treatment). Thus, Aj-GSSL-P1 represents GVBD inducing activity shown by the synthetic Aj-GSSL peptide, indicating AjGSSL-P1 peptide contains active site for GSSL activity. Furthermore, regarding Aj-GSSL-P1 concentration of $30 \mu \mathrm{g} / \mathrm{ml}$, it was 100 times more effective than the 3-10 kDa-fraction of RNE to achieve $80 \%$ of GVBD induction (Fig.1D).

The matured eggs induced by $12 \mu \mathrm{M}$ Aj-GSSL-P1 peptide were inseminated, and normally developed through to 8-day auricularia larval stage ensued and were similar to control eggs that matured spontaneously without aid of Aj-GSSL-P1.

\section{Discussion}

\section{Protein structure of Aj-GSSL}

The synthetic Aj-GSSL peptide had higher GVBD inducing activity $(6 \mu \mathrm{M})$ than RNE $(3 \mathrm{mg} / \mathrm{ml})$. The amino acid sequence of Aj-GSSL started with valine but not methionine, suggesting that this peptide is the product of proteolysis as is rather common property of neurohormones (Kandel et al., 2000; Levitan and Kaczmarek, 2002).

The GSS of starfish (e.g. Kanatani et al., 1971), sea urchin (Cochran and Engelmann, 1976), and sea cucumber (Maruyama, 1985) has similar heat stability. The relative molecular mass of $\mathrm{Aj}$ GSSL $(4.8 \mathrm{kDa})$ is similar to that of starfish $(4.5 \mathrm{kDa})$ (Yoshikuni, 2006) and sea urchin (5.6 kDa) (Cochran and Engelmann, 1976). However, unlike starfish GSS that is predicted to be a member of insulin family (Yoshikuni, 2006), the NCBI Protein BLAST analy-

\section{GVBD induced by synthetic Aj-GSSL peptide}

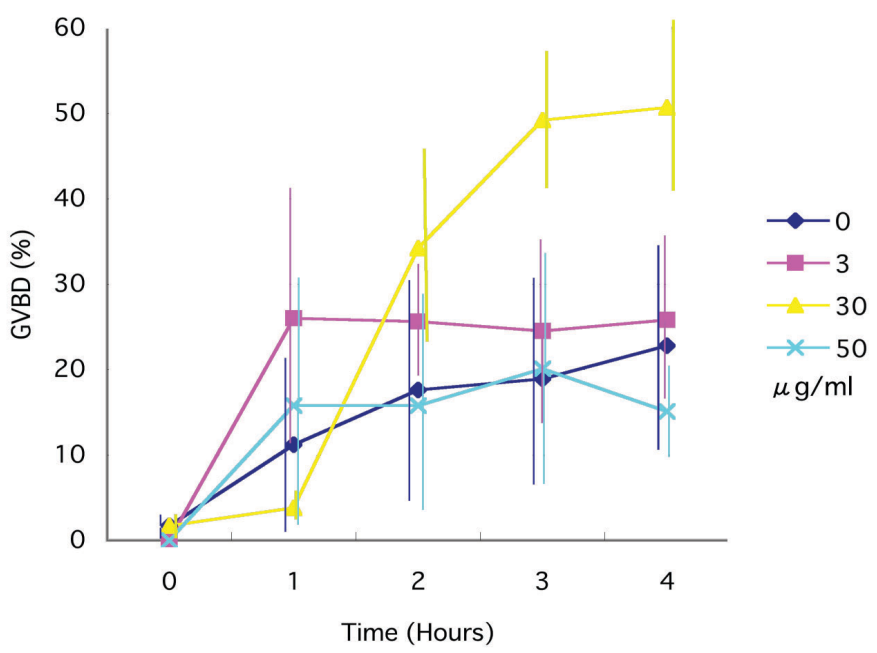

Fig. 5 (Left). Sequence analysis of the 43-amino acid peptide. (A) DNA and peptide sequences. Five potential trypsin cleavage sites were shown with underlined characters. The numbers below amino acid signature show that from $N$-terminal end. (B) The number of proteinases and potential their cleavage sites. Trp ${ }^{14}, \mathrm{Leu}^{26}, \mathrm{Il} \mathrm{e}^{34}$, and Phe ${ }^{35}$ show high probability of 5 to 6 proteinases cleavage.

Fig. 6 (Right). Germinal vesicle breakdown (GVBD) induction by synthetic 43-amino acid peptide. The synthetic peptide induced GVBD at 30 $\mu \mathrm{g} / \mathrm{ml}$ (yellow triangles) about 2 hours after application and prominently at 3 hours, whereas both lower $(3 \mu \mathrm{g} / \mathrm{ml}$, red squares) and higher (50 $\mu \mathrm{g} / \mathrm{ml}$, sky blue crosses) concentrations did not significantly induce GVBD. Dark blue diamonds show plain filtered sea water. Vertical bars show standard deviations. 
sis of Aj-GSSL depicted no significant similarities with insulin family molecules. Starfish GSS is a heterodimer that contains 6 cysteines, and thus are predicted to make 2 disulfide bonds between A- and B-chains and 1 intra-peptide disulfide bond in Achain. Aj-GSSL contained no cysteine residues, indicating no disulfide bonding, and thus is a single-chain peptide. That is different from known gonadotropin molecules, such as"luteinizing hormone and follicle stimulating hormone. While Aj-GSSL has GSSL-active structural domain that is comprised of 21 amino acids in N-terminal half of the peptide, starfish GSS requires intact heterodimeric structure to function (Mita et al., 2005). The number of potential proteolytic RX and $K X$ sites is different between starfish GSS and Aj-GSSL. In starfish GSS, only two sites in Bchain, $K^{2}$ and $R^{14}$, and none in A-chain, whereas Aj-GSSL contains 4 such sites $\left(\mathrm{K}^{3}, \mathrm{~K}^{36}, \mathrm{R}^{39}\right.$, and $\left.\mathrm{K}^{41}\right)$, and 3 of them are on the $\mathrm{C}$-terminal side, suggesting the presence of potential vulnerability of Aj-GSSL to environmental proteases. Although peptideto-peptide sequencing analysis to dozens of peptides smaller than $3 \mathrm{kDa}$ found in the 3-10 kDa-fraction by MALDI-TOF MS

\section{A}

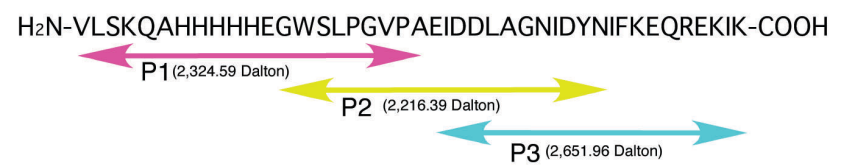

B

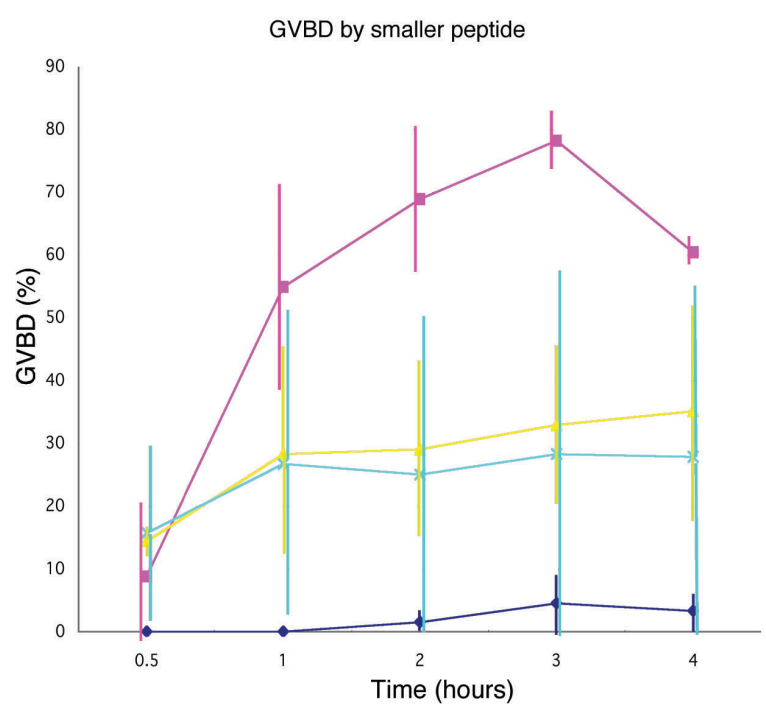

Fig. 7. A shorter amino acid sequence that holds germinal vesicle breakdown (GVBD) inducing activity at $\mathbf{3 0} \boldsymbol{\mu \mathbf { g }} / \mathbf{m l}$. (A) Amino acid sequence of Aj-GSSL-P1, -P2 and-P3 peptides. Aj-GSSL-P1 comprises Nterminal half of Aj-GSSL. Aj-GSSL-P2 involves C-terminal part of -P1 and $N$-terminal part of -P3. Aj-GSSL-P3 comprises C-terminal half of the synthetic peptide. Aj-GSSL-P1 and -P3 do not have overlapped amino acid. (B) GVBD induced by Aj-GSSL-P1, -P2 and -P3, respectively. AjGSSL-P1 showed distinctive GVBD induction activity (closed circles), particularly from 2 hours after treatment and reached a peak at 3 hours, whereas -P2 (open circles) and -P3 (open rectangles) induced only a little. Closed rectangles show plain filtered sea water. Vertical bars show standard deviations. analysis (Fig.2A) has not applied, at least 11 major peptides (more than $30 \%$ Intensity), from 524.8 to 2741.23 Dalton, were seen, and the $3 \mathrm{kDa}>-$ fraction induced GVBD in about $40 \%$ of immature oocytes at $300 \mu \mathrm{g} / \mathrm{ml}$ (Fig.1D). It appears that smaller peptide fragments retained GSSL activity in some extent.

\section{Aj-GSSL immunolocalization}

Aj-GSSL locates in 6-7 $\mu \mathrm{m}$ diameter granules in the cells that distributed primarily on the surface of the radial nerve at hyponeural part and in the epineural sinus. The distribution of Aj-GSSL on the radial nerve surface resembles the presumed starfish GSS distribution in the supporting cell layer on the surface of the radial nerve of starfish, Marthasterias glacialis (de Angelis et al., 1972). The morphology of granular cells resembles that of morula cells in connective tissue (Byrne, 1986). They accumulate around wounded area, and their contents seem to be heterogeneous (San Miguel-Ruiz and García-Arrarás, 2007). They more resemble the neurosecretory cells of insect shown in vitro, such as the brain neurosecretory cells of cockroaches (Seshan and LeviMontalcini, 1973) and the medial neurosecretory cells of the pars intercerebralis of the supraoesophageal ganglion of Locusta migratoria (Rössler and Bickmeyer, 1993). The present granular cells extend fibers towards the surrounding tissues that again resemble axons elongating from the clusters of neurosecretory cells in above insects, and this suggests the presence of $\mathrm{Aj}$ GSSL-ergic nervous system that innervating throughout the tissues and organs, at least, around the radial nerve. This may implicate some function of Aj-GSSL other than GSS activity.

The abundance of granular cells in the ectoneural sinuses suggests that there may be an Aj-GSSL delivery system to the circular sinus on the anterior face of the circumoral nerve ring (Smiley, 1994). The accumulation of Aj-GSSL in granular cells near the apical surface of the coelomic epithelium in the epineural sinus suggests that the radial nerve tissue may associate with $\mathrm{Aj}$ GSSL deliberation via these granular cells.

\section{GVBD inducing activity of Aj-GSSL}

One problem with conducting the bioassay with sea cucumber is the asynchronous pattern of oogenesis through the breading season (Inaba, 1957). This caused a variation in the sensitivity of ovarian regions to Aj-GSSL in bioassay. However, a high rate of GVBD by RNE was observed, and in the 3-10 kDa-fraction as reported by Maruyama (1985). None of spilled immature oocytes from fecund fragments with no follicle cell layer showed GVBD by RNE treatment (data not shown). The time delay (about 3 hours) in GVBD after the treatment of Aj-GSSL at $30 \mathrm{mg} / \mathrm{ml}$ is similar to that of starfish GSS activity (Kanatani et al., 1969). This shows that GVBD inducing activity is represented by 43-amino acid synthetic Aj-GSSL peptide. This also implicates indirect function of Aj-GSSL for GVBD, may be through presumed 2,8-disubstituted adenine as a secondary messenger (Smiley, 1990). Although the mechanism how activity of synthetic Aj-GSSL suppressed GVBD at higher concentration (Fig.6) that also was seen in the $3 \mathrm{kDa}>-$ fraction of RNE in similar manner (Fig.1D) ought to be elucidated, it would be a possible interpretation that overdosed application of Aj-GSSL or Aj-GSSL active peptide fragments in the $3 \mathrm{kDa}>$-fraction down-regulates its receptor expression as is known in peptide hormone action mechanism, such as insulin binding. It has been known that continuous exposure of 
lymphocytes to insulin results in the down-regulation of insulin receptor expression on the cells (Harrison et al., 1982; Brown et al., 1983).

Unlike starfish GSS, Aj-GSSL is a single peptide chain with no cysteines, excluding intra-peptide disulfide bonding as well. The GSSL activity was represented by Aj-GSSL-P1 peptide, about the half size of the 43-amino acid Aj-GSSL. Its functional time course, again, resembled $\mathrm{Aj}$-GSSL peptide with a few hours of lag time to induce GVBD at $12 \mu \mathrm{M}$ that was a little higher concentration to induce GVBD than Aj-GSSL. However, Aj-GSSL-P1 induced GVBD to significantly higher percentage of immature oocytes (Fig.7). Thus, Aj-GSSL-P1 well represents GSSL activity of RNE with considerably higher activity. Although GSSL activity of other smaller peptides, Aj-GSSL-P2 and -P3, were considerably lower than $-P 1$, they too retained weaker GSSL activity. This seems to be consistent with the present observation of weak but statistically significant GSSL activity of the $3 \mathrm{kDa}>$-fraction (Fig.1) that contained 8 major but smaller peptides that ranged from 1,973 to 2,741 Dalton (Fig.2). Although protein sequencing needs to be done onto each of these peptide, regarding their sizes, particularly 6 peptides that have similar or larger than Aj-GSSL-P1 peptide (2,324 Dalton) size (Fig.2A), and the presence of significantly fewer number of pronase target sites in the $\mathrm{N}$-terminal half than the C-terminal half of Aj-GSSL peptide, at least, some of these 6 peptides in the $3 \mathrm{kDa}>$-fraction may hold the amino acid sequence present in Aj-GSSL-P1 peptide.

Characteristic structure of Aj-GSSL-P1 peptide was fivehistidine sequence $\left(\mathrm{His}^{7}-\mathrm{His}^{11}\right)$ between two potential pronase target amino acids, Leu $^{2}$ and $\operatorname{Trp}^{14}$, indicating the sequence is stable to pronase digestion. Although particular biological function of histidine-rich sequence in general is yet to be elucidated, at least the sequence is involved in cyclin $\mathrm{T} 1$ binding to $\mathrm{C}$-terminal domain of RNA polymerase II during gene transcription (Zhan et al., 2003). The mechanism how Aj-GSSL-P1 induces GVBD ought to be elucidated.

\section{Materials and Methods}

\section{Animals}

Adults of sea cucumber, Apostichopus japonicus, were collected either in the vicinity of The Research Center for Marine Biology, Tohoku University or shipped from Wakkanai, Hokkaido, and Kawa-uchi, Aomori.

\section{Radial nerve extraction and fractionation by ultrafiltration mem- brane}

The radial nerves were dissected along with surrounding tissues that included its overlaying epithelia of the radial canal and body wall, washed with filtered sea water (FSW) twice, wiped FSW with paper towel, and minced to small pieces by razor blades on ice. Two grams (wet weight) of the sample was mixed with $5 \mathrm{ml}$ of sterilized distilled water (DW), and homogenized by a glass homogenizer at $300 \mathrm{rpm}$ for $10 \mathrm{~min}$ on ice. The homogenate was centrifuged at $4,000 \times G$ for $30 \mathrm{~min}$ at $4^{\circ} \mathrm{C}$, and collected the supernatant (radial nerve extract, RNE). Protein content of RNE was estimated with a UV/Visible Spectrophotometer (Ultraspec 2000, Pharmacia Biotech, Tokyo, Japan) at $A_{280}$ using bovine serum albumin dissolved in DW as standards. Since GSS was reported to be effectively released from the radial nerve by heat application (Kanatani et al., 1971; Cochran and Englemann, 1976), RNE was then heated at $100^{\circ} \mathrm{C}$ for 15 min. RNE was freeze-dried with a VD-800F Freeze Dryer (TAITEC, Koshigaya, Japan), and stored at $4^{\circ} \mathrm{C}$ until use. Since it has been reported that GSS activity is retained in the peptide(s) with molecular weight of several kilo Daltons (Maruyama, 1985), $80 \mathrm{mg}$ of the freeze-dried RNE was diluted in $15 \mathrm{ml}$ of sterilized DW and centrifuged at $15,000 \times \mathrm{x}$ for $20 \mathrm{~min}$ at ambient temperature, and its supernatant was further fractionated with a Ultrafiltration membrane Centriprep Centrifugal Filter Devices YM10 (CCFD YM10, Amicon, Millipore Co. Bedford, USA) to separate the proteins larger than $10 \mathrm{kDa}$ and the ones smaller than that at $1,000 \times \mathrm{G}$ at $4^{\circ} \mathrm{C}$. The filtrated samples were further separated the peptides smaller than $3 \mathrm{kDa}$ with CCFD YM3 (Amicon, Millipore Co.) at 1,000xG at $4^{\circ} \mathrm{C}$ (3kD>-fraction). The samples that did not pass through the CCDF YM3 membrane were collected as the peptides between $3 \mathrm{kDa}$ and $10 \mathrm{kDa}$ (3$10 \mathrm{kDa}$-fraction). Amount of protein in the $3 \mathrm{kDa}>$ and the 3-10 kDafractions were estimated at $A_{280}$, freeze dried as stated above, and stored at $4^{\circ} \mathrm{C}$ until use. RNE, $10-30 \mathrm{kDa}-$ and $3 \mathrm{kDa}>-$ fractions were diluted in FSW at appropriate concentrations, respectively, and used for bioassay as is stated in this section.

\section{MALDI-TOF MS analysis}

According to the present bioassay, 3-10 kDa-fraction of RNE had strong GVBD inducing activity as stated above in Results. To specify GVBD induction active molecule, protein masses in the 3-10 kDa-fraction were measured on a matrix-assisted laser-desorption ionization time-offlight mass spectrometry (MALDI-TOF MS, Voyager-DE Pro, Applied Biosystems, Foster City, CA. USA) (Landry et al., 2000). For MALDI-TOF MS analysis, the isolated protein in the 3-10 kDa-fraction was freed from reagents using a C18 Zip-Tip pipette tip (Millipore Co.) after activation with $70 \%$ acetonitrile and equilibration in $0.1 \%$ trifluoroacetic acid (TFA). Following protein absorption and washing with $0.1 \%$ TFA, proteins were eluted with $10 \mu \mathrm{l}$ of $70 \%$ acetonitrile. An equal volume $(0.5 \mu \mathrm{l})$ of the protein solution and the matrix (sinapinic acid, Sigma, saturated in $50 \%$ acetonitrile and $0.1 \%$ TFA) were mixed on the MALDI-TOF plate. The molecular masses of the proteins were determined with an Applied Biosystems Voyager-DE Pro mass spectrometer operated in reflector mode.

\section{Internal amino acid sequencing}

The 3-10 kDa-fraction of RNE was dissolved in SDS-PAGE samples buffer under reducing condition with dithiothreitol (DTT) and separated on 5-well, $1 \mathrm{~mm}$ thick, $18 \%$ SDS-PAGE slab gels. Each well was loaded with $730 \mu \mathrm{g}$ of 3-10 kDa-fraction sample and stained with MS silver stain kit (Wako pure chemical) for further protein sequencing. A $4.8 \mathrm{kDa}$ band region were dissected from 6 lanes of the slab gels with razor blades. The gel pieces were washed with sterilized distilled water twice, and digested with trypsin in Tris buffer at $\mathrm{pH} 8.0$ for 20 hours at $35^{\circ} \mathrm{C}$. A Waters-HPLC System (Waters Co. Milford, MA. USA) was employed. A $50 \mu$ l of sample solution was injected into Symmetry C18 $3.5 \mu \mathrm{m}(150 \mathrm{~mm}$ long $\times 1.0 \mathrm{~mm}$ internal diameter, Waters Co.) and eluted with a mixture of solvent $A$ (0.1\% TFA in $2 \%$ acetonitrile) and solvent B $(0.09 \%$ TFA in $90 \%$ acetonitrile) using $0-100 \%$ B gradient (0min 0\%, 0\% 6min, 10\% $11 \mathrm{~min}, 50 \%$ $86 \mathrm{~min}, 100 \% 91 \mathrm{~min}, 100 \% 96 \mathrm{~min}$, and $0 \% 101 \mathrm{~min}$ ) over $100 \mathrm{~min}$ at a flow rate of $50 \mu \mathrm{l} / \mathrm{min}$. The UV/visible signal was recorded at $210 \mathrm{~nm}$ and $280 \mathrm{~nm}$. A fraction of HPLC sample was chosen and analyzed for sequencing with a Procise $494 \mathrm{cLC}$ Protein Sequencing System (Applied Biosystems, USA) for 12 cycles.

\section{Antiserum generation}

Antiserum against Aj-GSSL peptide was raised according to the technique described before (Katow et al., 2004). Briefly, a synthetic peptide of 12 amino acids sequence elucidated from above protein sequencing was tagged with Key hole limpet hemocyanin at N-terminal end via cysteine. The antigen peptide was dissolved in Gerbu adjuvant 100 (Gerbu Biotech GmbH, Gailberg, Germany) diluted 1:1 in sterilized $\mathrm{DW}$ at $1.5 \mathrm{mg} / \mathrm{ml}$, and $100 \mu \mathrm{l}$ of antigen/adjuvant mixture was injected to the peritoneal of three mice at every 7 to 10 days. Generation of antiserum was examined using tail bleed by immunohistochemistry and immunoblotting. Then $1 \times 10^{7} \mathrm{SP} 2$ myeloma cells in $1 \mathrm{ml}$ of GIT culture 
medium (Nihon Pharmaceutical Co. Ltd. Tokyo, Japan) were injected to the peritoneal cavity of mice to produce ascitic fluid. The ascitic fluid was further separated blood clot and serum. The serum was used as anti-AjGSSL serum for immunochemistry.

\section{Immunochemical analysis}

The radial nerve and surrounding tissues were dissected and fixed in $4 \%$ paraformaldehyde in FSW, dehydrated in increasing concentration of ethanol, and embedded in Polywax as described before (Katow, 1995). Thin sections were made at about $6 \mu \mathrm{m}$, and used for immunohistochemistry after dewaxing. Anti-Aj-GSSL antiserum was dissolved 1:100 in $0.1 \mathrm{M}$ phosphate buffered saline with $0.1 \%(\mathrm{v} / \mathrm{v})$ of Tween-20 (PBST) and applied overnight at $4^{\circ} \mathrm{C}$ in moist chamber. The antiserum was probed with 1:500 diluted Alexa Fluor 594 or 488-conjugated goat anti-mouse IgG $(\mathrm{H}+\mathrm{L})$ antibody (Molecular Probes Inc., Eugene, OR. USA) in PBST, and examined under a Micro-Radiance 2000 confocal laser scanning microscope (BioRad, Hercules, CA). To specify immunospecificity of the antiserum, $3 \mathrm{mg} / \mathrm{ml}$ of the antigen peptide was applied with 1:500 diluted anti-Aj-GSSL antiserum for competitively inhibiting the antiserum binding, and immunoreaction was examined as stated above. Some of the specimens were double stained with $1 \mu \mathrm{g} / \mathrm{ml}$ propidium iodide for $10 \mathrm{~min}$ to locate nuclei. For immunoblotting, RNE was dissolved in SDS-PAGE sample buffer under reducing condition with DTT at $1 \mathrm{mg} / \mathrm{ml}$, and separated on $18 \%$ SDS-PAGE slab gels as stated above. The peptide was electroblotted to nitrocellulose filters according to the method by Towbin et al.,1979), blocked with 5\% (w/v) skim milk in TBST for 1 hour, and probed with alkaline phosphatase-conjugated goat anti-mouse IgG antibody (Sigma, St. Louis, MO) diluted 1:30,000 in TBST for 2 hours. The immunoreaction was visualized with nitrobluetetrazolium/5-bromo-4chloro-3-indolyl phosphate (NBT/BCIP, Promega) according to the manufacturer's protocol. To specify immunospecificity of the antiserum, RNE sample was blotted, and applied $1 \mathrm{mg} / \mathrm{ml}$ of the peptide in $1: 1,000$ diluted antiserum solution for competitively inhibiting the antiserum binding. Immunoreaction was visualized as stated above.

\section{DNA and protein sequencing}

To obtain 5' and 3' termini of the cDNA that encodes the 12-amino acid sequence found by above internal amino acid sequencing, the radial nerve was dissected from adult body wall, cut into small pieces with razor blades on ice, and total RNA was obtained using ISOGEN (Nippon Gene, Tokyo, Japan). Poly (A)+ RNA was extracted from the total RNA by Oligotex dT-30 SUPER (TAKARA, Otsu, Japan). Single-strand cDNA were made from the poly $(A)+$ RNA by reverse transcriptase, Super Script II (Invitrogen, Tokyo, Japan), and oligo-d(T) primer (Invitrogen). Based on the present partial amino acid sequence described elsewhere in this paper, the following 2 degenerate primers and 2 Notl tag1 primers were used for 3' RACE: Aj-GSSL-iF1, GCNGARATHGAYGAYYTNGCNGG; Aj-GSSL-iF, GCNGARATHGAYGAYYTNGCNGGNAAYATHGAYTA (R: $\mathrm{A} / \mathrm{G}, \mathrm{H}: \mathrm{A} / \mathrm{C} / \mathrm{T}, \mathrm{Y}: \mathrm{C} / \mathrm{T}, \mathrm{N}: \mathrm{A} / \mathrm{G} / \mathrm{C} / \mathrm{T}, \mathrm{M}: \mathrm{A} / \mathrm{C})$, Notl tag27: AACTGGAAGAATTCGCGGCCGCAGGAA; Notl tag1: AACTGGAAGAATTCGCGG. 1st PCR was conducted using Aj-GSSL-iF and Not1 tag27 primers, and 2nd PCR was with Aj-GSSL-iF1 and Notl tag1 primers.

After agarose gel electrophoresis, a single band at 150bp was cut from the gel, purified with Wizard PCR Preps DNA purification System (Promega), and ligated to pGEM-T Vector (Promega). Sequence analysis was conducted using a Texas Red labeling M13 primers with a DNA sequencer HITACHI SQ-5500 model. Based on this sequence, the following 2 primers were used for 5' RACE: Oligo d(T) anchor primer (Roche Diagnostics K.K., Tokyo), Aj-GSSL-iR1: CCNGCNARRTCRTCDATYTCNGC.

Protein sequence was deduced from cDNA sequence. Potential proteolytic sites by 18 pronases (Arg-C proteinase, Asp- $\mathrm{N}$ endopeptidase, Asp-N endopeptidase + N-terminal Glu, BNPS-Skatole, Chymotrypsin-high specificity (C-term to [FYW], not before $\mathrm{P}$ ), Chymotrypsin-low specificity (C-term to [FYWML], not before P), Clostripain, Formic acid, Glutamyl endopeptidase, lodosobenzoic acid, LysC, LysN, Pepsin $(\mathrm{pH}$ 1.3), Pepsin $(\mathrm{pH}>2)$, Proteinase K, Staphylococcal peptidase I, Thermolysin, and Trypsin) were estimated by ExPASy: PeptideCutter (http://www.expasy.ch/tools/peptidecutter).

\section{Bioassay}

To examine GVBD inducing activity of the RNE in vitro, the ovaries were eviscerated along with other internal organs from adult sea cucumbers by injecting $0.3 \mathrm{MKCl}$. The fecund tubes staffed with immature oocytes of about $1 \mathrm{~mm}$ diameter were used for bioassay. Prior to in vitro bioassay in 24-well plates, the fecund tubes were dissected into $1 \mathrm{~cm}$-long pieces, and washed twice with fresh FSW to discard the immature oocytes spilled by dissection. Each of these $1 \mathrm{~cm}$ long piece of fecund tube was placed in the wells that were filled with $1 \mathrm{ml}$ of FSW that dissolved $300 \mu \mathrm{g} / \mathrm{ml}$ or $3 \mathrm{mg} / \mathrm{ml}$ of the RNE prepared as stated above, and was incubated for 2 hours at $23^{\circ} \mathrm{C}$. The experiment was repeated 3 to 8 times using different ovaries. Since estimated relative molecular mass of GVBD induction active factor is a few kilo Daltons (Maruyama, 1985), the RNE was further separated to two fractions using ultrafiltlation membrane as stated above; a fraction smaller than $3 \mathrm{kDa}$ (3 kDa>-fraction) and that between $3 \mathrm{kDa}$ and $10 \mathrm{kDa}$ (3-10 kDa-fraction) as stated above. The $1 \mathrm{~cm}-$ long pieces of fecund tubes were incubated in $1 \mathrm{ml}$ of FSW that contained the $3 \mathrm{kDa}>$-fraction at $300 \mu \mathrm{g} / \mathrm{ml}$ or $3 \mathrm{mg} / \mathrm{ml}$ or in the $3-10 \mathrm{kDa}$-fraction at $300 \mu \mathrm{g} / \mathrm{ml}$ or $3 \mathrm{mg} / \mathrm{ml}$.

The bioassay of synthetic peptides was conducted in the wells of 24well plates as stated above. To examine GVBD induction by the 43-amino acid synthetic Aj-GSSL peptide (Theoretical molecular mass $=4,958.53$ Dalton), $3(0.6 \mu \mathrm{M}), 30(6 \mu \mathrm{M})$ and $50 \mu \mathrm{g} / \mathrm{ml}(10 \mu \mathrm{M})$ of the peptides were dissolved in FSW. The number of eggs that showed GVBD was counted under a dissection microscope at the time of the onset of treatments and every one-hour after that for 4 hours. At each time the counted eggs and immature oocytes were discarded from the well. The examination was repeated three times.

To estimate GSSL activity of shorter peptide, the Aj-GSSL was separated to the following three shorter peptides. Aj-GSSL-P1: $\mathrm{H}_{2} \mathrm{~N}$ VLSKQAHHHHHEGWSLPGVPA-COOH, Aj-GSSL-P2: $\mathrm{H}_{2} \mathrm{~N}-$ GWSLPGVPAEIDDLAGNIDYN-COOH, and Aj-GSSL-P3: $\mathrm{H}_{2} \mathrm{~N}-$ EIDDLAGNIDYNIFKEQREKIK-COOH (Fig.7). The bioassay for shorter peptides also was conducted as stated above by immersing $1 \mathrm{~cm}$ long pieces of fecund tubes in $1 \mathrm{ml}$ of FSW that dissolved $30 \mu \mathrm{g} / \mathrm{ml}$ of Aj-GSSL$\mathrm{P} 1(13 \mu \mathrm{M}),-\mathrm{P} 2(13 \mu \mathrm{M})$ or -P3 $(11 \mu \mathrm{M})$ peptide for 4 hours. The number of immature oocytes that showed GVBD was counted under a dissection microscope, and the total number of eggs and immature oocytes counted during bioassay was stated in the text. The examination was repeated three times, and average percent of GVBD was summarized in a graph with standard deviations.

\section{Acknowledgements}

This study has been supported by the grant from the Prefecture of Aomori, New Industry Promoting Program. We thank Dr. M. Byrne, University of Sydney, for valuable suggestion and critically reading the manuscript, and M. Washio, Tohoku University, Research Center for Marine Biology, for raising SP2 myeloma and collecting animals. We also thank Soya Fishermen's Union, Kawa-uchi Fishermen's Union for collecting animals for this study.

\section{References}

BEER, A.J., MOSS, C., and THORNDYKE, M. (2001). Development of serotoninlike and SALMFamide-like immunoreactivity in the nervous system of the sea urchin Psammechinus miliaris. Biol. Bull. 200: 268-280.

BISHOP, C.D., and BURKE, R.D. (2007). Ontogeny of the holothurian larval nervous system: evolution of larval forms. Dev. Genes Evol. 217: 585-592.

BROWN, T.J., ERCOLANI, L., and GINSBERG, B.H. (1983). Properties and 
regulation of the T lymphocyte insulin receptor. J. Recept. Res. 3:481-494.

BURKE, R.D., ANGERER, L.M., ELPHICK, M.R., HUMPHREY, G.W., YAGUCHI, S., KIYAMA,T., LIANG, S., MU, X., AGCA, C., KLEIN, W.H., BRANDHORST, B.P., ROWE, M., WILSON, K., CHURCHER, A.M., TAYLOR, J.S., CHEN, N., MURRAY, G., WANG, D., MELLOT, D., OLINSKI, R., HALLBOOK, F., and THORNDYKE, M.C. (2006). A genomic view of the sea urchin nervous system. Dev. Biol. 300: 434-460

BYRNE, M. (1986). The ultrastructure of the morula cells of Eupentacta quimquesemita (Echinodermata: Holothuroidea) and their role in the maintenance of the extracellular matrix. J. Morphol. 188: 179-189.

BYRNE, M., CISTERNAS, P., ELIA, L., and RELF, B. (2005). Engrailed is expressed in larval development and in the radial nervous system of Patiriella sea stars. Dev. Genes Evo. 215: 608-617.

BYRNE, M., SEWELL, M.A., SELVAKUMARASWAMY, P., and PROWSE, T.A.A. (2006). The larval apical organ in the holothuroid Chiridota gigas (Apodia): Inference on evolution of the Ambulacraria larval nervous system. Biol. Bull. 211: 95-100.

COCHRAN, R.C., and ENGELMANN, F. (1976). Characterization of spawn-inducing factors in the sea urchin, Strongylocentrotus purpuratus. Gen. Comp. Endocrinol. 30: 189-197.

DE ANGRLIS, E., VIGLIA, A., WATANABE, T., SHIRAI, H., KUBOTA, J., KANATANI, $H$. (1972). Presence of granules containing gonad-stimulating substance in starfish radial nerve. Annot. Zool. Japan 45:16-21.

DE BREMAEKER, N., DEHEYN, D., THORNDDYKE, M.C., BAGUET, F., and MALLEFET, J. (1997). Localization of S1- and S2-like immunoreactivity in the nervous system of the brittle star Amphipholis squamata (Delle Chiaje 1828). Proc. Royal Soc. London - Series B: Biol. Sci. 264: 667-674.

DIAZ-BALZAC, C.A., SANTACANA-LAFFITTE, G., SAN MIGUEL-RUIZ, J.E., TOSSAS, K., VALENTIN-TIRADO, G., RIVES-SANCHEZ, M., MELSLEH, A., TORRES, I.I., and GARCÍA-ARRÁS.J.E. (2007). Identification of nerve plexi in connective tissues of the sea cucumber Holothuria glaberrima by using a novel nerve-specific antibody. Biol. Bull. 213: 28-42.

DIAZ-MIRANDA, L., BLANCO, R.E., and GARCÍA-ARRÁS, J.E. (1995). Localization of the heptapeptide GFSKLYFamide in the sea cucumber Holothuria glaberrima (Echinodermata): a light and electron microscopic study. J. Comp. Neurol. 352: 626-640.

ELPHICK, M.R., NEWMAN, A J., and THORNDYKE, M.C. (1995). Distribution and action of SALMFamide neuropeptides in the starfish Asterias rubens J. Exp. Biol. 198: 2519-2525.

GARCÍA-ARRÁS, J.E., ENAMORADO-AYALA, I., TORRES-AVIILAN, I., and RIVERA, V. (1991). FMRFamide-like immunoreactivity in cells and fibers of the holothurian nervous system. Neurosci Lett. 132:199-202

HARRISON, L.C., ITIN, A., KASUGA, M., and VAN OBBERGHEN, E. (1982). The insulin receptor on the human lymphocyte: insulin-induced down-regulation of 126,000 and 90,000 glycosylated subunits. Diabetologia 22: 233-238.

HIROKAWA, T., KOMATSU, M., and NAKAJIMA, Y. (2008). Development of the nervous system in the brittle star Amphipholis kochii. Dev. Genes Evol. 218:1521.

INABA, D. (1957). Sea cucumbers. In "Developmental Biology of Invertebrates" (Kume M and Dan K eds) (in Japanese) pp. 223-236. Baifukan, Tokyo.

INOUE, M., TAMORI, M., and MOTOKAWA, T. (2002). Innervation of holothurian body wall muscle: Inhibitory effects and localization of 5-HT. Zool. Sci. 19: 12171222.

KANATANI, H. (1967). Mechanism of starfish spawning with special reference to gonad-stimulating substance (GSS) of nerve and meiosis-inducing substance (MIS) of gonad. Jap. J. Exp. Morphol. 21: 61-78.

KANATANI, H., SHIRAI, H., NAKANISHI, K., and KUROKAWA, T. (1969). Isolation and identification of the meiosis inducing substance in the starfish Asterinas amurtensis. Nature 221: 273-274.

KANATANI, H., IKEGAMI, S., SHIRAI, H., OIDE, H., and TAMURA, T. (1971). Purification of gonad-stimulating substance obtained from radial nerves of the starfish, Asterias amurensis. Dev. Growth Differ. 13: 151-164.

KANDEL, E.R., SCHWARTZ, J.H., and JESSELL, T.M. (2000). Principles of Neural Science, 4th edn. McGraw-Hill,Tokyo.
KATOW, H. (1995). Pamlin, a primary mesenchyme cell adhesion protein, in the basal lamina of the sea urchin embryo. Exp. Cell Res. 218: 469-478.

KATOW, H., YAGUCHI, S., KIYOMOTO, M., and WASHIO, M. (2004). The 5-HT receptor cell is a new member of secondary mesenchyme cell descendants and form a major blastocoelar network in sea urchin larvae. Mech. Dev. 121: 325337.

KATOW, H., YAGUCHI, S., and KYOZUKA, K. (2007). Serotonin stimulates $\left[\mathrm{Ca}^{2+}\right]_{\mathrm{i}}$ elevation in ciliary ectodermal cells of echinoplutei through a serotonin receptor cell network in the blastocoel. J. Exp. Biol. 210: 403-412.

KATOW, H. (2008). Spatio-temporal expression of a Netrin homolog in the sea urchin Hemicentrotus pulcherrimus (HpNetrin) during serotonergic axon extension. Int. J. Dev. Biol. 52:1077-1088.

LANDRY, F., LOMBARDO, C.R., and SMITH, J.W. (2000). A method for application of samples to matrix-assisted laser desorption ionization time-of-flight targets that enhances peptide detection. Anal. Biochem. 279: 1-8.

LEVITAN, I.B., and KACZMAREK,L.K. (2002). The Neuron: Cell and Molecular Biology, 3rd edn. Oxford Univ Press, Tokyo.

MARUYAMA, Y.K. (1985). Holothurian oocyte maturation induced by radial nerve. Biol. Bull. 168: 249-262.

MITA, M., OKA, H., THORNDYKE, M.C., SHIBATA, Y., YOSHIKUNI, M., and NAGAHAMA, Y. (2004). Inhibitory effect of a SALMFamide neuropeptide on secretion of gonad-stimulating substance from radial nerves in the starfish Asterina pectinifera. Zool. Sci. 21: 299-303.

MITA, M., YOSHIKUNI, M., OHNO, K., PITCHAYAWASIN, S., ISOBE, M., and NAGAMAHA, Y. (2005). Hormonal activity of synthetic gonad-stimulating substance (GSS) which is a gonadotropin of starfish, Asterina pectinifera. Zool. Sci. 22: 1499 (Abstract)

MITA, M., YAMAMOTO, K., YOSHIKUNI, M., OHNO, K., and NAGAHAMA, Y. (2007). Preliminary study on the receptor of gonad-stimulating substance (GSS) as a gonadotropin of starfish. Gen. Comp. Endocrinol. 153: 299-301.

NAKAJIMA, Y., KANEKO, H., MURRAY, G., and BURKE, R.D. (2004). Divergent patterns of neural development in larval echinoids and asteroids. Evo. Dev. 6: 95-104.

RÖSSLER, W., and BICKMEYER, U. (1993). Locust medial neurosecretory cells in vitro: Morphology, electrophysiological properties and effects of temperature. J. Exp. Biol. 183: 323-339.

SAN MIGUEL-RUIZ, J.E., and GARCÍA-ARRÁS.J.E. (2007). Common cellular events occurs during wound healing and organ regeneration in the sea cucumber Holothuria glaberrima. BMC Dev. Biol. 7:115-123.

SESHAN, K.R., and LEVI-MONTALCINI, R. (1973). Neuronal properties of nymphal and adult insect neurosecretory cells in vitro. Science 182: 291-293.

SLY, B.J., HAZEL, J.C., POPODI, E.M., and RAFF, R.A. (2002). Patterns of gene expression in the developing adult sea urchin central nervous system reveal multiple domains and deep-seated neural pentamery. Evo. Dev. 4:189-204.

SMILEY, S. (1990). A review of echinoderm oogenesis Electron microsc. Tech. 16: 93-114.

SMILEY, S. (1994). Holothuria, In "Microscopic Anatomy of Invertebrates", Vol. 14: Echinodermata. (Harrison $\mathrm{F}$ and Chia F-S eds), pp. 401-471. Wiley-Liss, Inc, New York.

STRATHMANN, R.R., and SATO, H. (1969). Increased germinal vesicle breakdown in oocytes of the sea cucumber Parastichopus californicus induced by starfish radial nerve extract. Exp. Cell Res. 54: 127-129.

TOWBIN, H., STAEHELIN, T., and GORDON, J. (1979). Electrophoretic transfer of proteins from acrylamide gels to nitrocellulose sheets: procedure and application. Proc. Natl. Acd. Sci. USA 76: 4350-4354.

YAGUCHI, S., and KATOW, H. (2003). Expression of tryptophan 5-hydroxylase gene during sea urchin neurogenesis and role of serotonergic nervous system in larval behavior. J. Comp. Neurol. 466: 219-229.

YOSHIKUNI, M. (2006). Gonad stimulating hormone and insulin family of echinoderm. Nihon Comparative Endocrinology News 123: 13-20 (in Japanese)

ZHANG, F., BARBORIC, M., BLACKWELL, K.T., and PETERLIN, M.B. (2003). A model of repression: CTD analogs and PIE-1 inhibit transcriptional elongation by P-TEFb. Genes Dev. 17: 748-758. 


\section{Further Related Reading, published previously in the Int. J. Dev. Biol.}

See our recent Special Issue Fertilization, in honor of David L. Garbers and edited by Paul M. Wassarman and Victor D. Vacquier at: http://www.ijdb.ehu.es/web/contents.php?vol=52\&issue=5-6

The distribution and behavior of extragonadal primordial germ cells in Bax mutant mice suggest a novel origin for sacrococcygeal germ cell tumors

Christopher Runyan, Ying Gu, Amanda Shoemaker, Leendert Looijenga and Christopher Wylie

Int. J. Dev. Biol. (2008) 52: 333-344

Defective calcium release during in vitro fertilization of maturing oocytes of LT/Sv mice

Karolina Archacka, Anna Ajduk, Pawel Pomorski, Katarzyna Szczepanska, Marek Maleszewski and Maria A. Ciemerych

Int. J. Dev. Biol. (2008) 52: 903-912

The role of the actin cytoskeleton in calcium signaling in starfish oocytes

Luigia Santella, Agostina Puppo and Jong Tai Chun

Int. J. Dev. Biol. (2008) 52: 571-584

Centroid, a novel putative DEAD-box RNA helicase maternal mRNA, is localized in the mitochondrial cloud in Xenopus laevis oocytes

Malgorzata Kloc and Agnes P. Chan

Int. J. Dev. Biol. (2007) 51: 701-706

Isolation of apoptotic mouse fetal oocytes by AnnexinV assay

Anna-Maria Lobascio, Francesca-Gioia Klinger and Massimo De Felici

Int. J. Dev. Biol. (2007) 51: 157-160

Dynamic distribution of the replacement histone variant $\mathrm{H} 3.3$ in the mouse oocyte and preimplantation embryos Maria-Elena Torres-Padilla, Andrew J. Bannister, Paul J. Hurd, Tony Kouzarides and Magdalena Zernicka-Goetz Int. J. Dev. Biol. (2006) 50: 455-461

Delivery of germinal granules and localized RNAs via the messenger transport organizer pathway to the vegetal cortex of Xenopus oocytes occurs through directional expansion of the mitochondrial cloud Katarzyna Wilk, Szczepan Bilinski, Matthew T. Dougherty and Malgorzata Kloc Int. J. Dev. Biol. (2005) 49: 17-21

P450 aromatase expression in the temperature-sensitive sexual differentiation of salamander (Hynobius retardatus) gonads

Natsuko Sakata, Yoichiro Tamori And Masami Wakahara

Int. J. Dev. Biol. (2005) 49: 417-425

Paracrine actions of oocytes in the mouse pre-ovulatory follicle.

A Salustri

Int. J. Dev. Biol. (2000) 44: 591-597

Age and gonadotropins control Ca2+-spike acquisition in mouse oocytes isolated from early preantral follicles.

J E Gomes, A Pesty, A Gouveia-Oliveira, A J Cidadão, C E Plancha and B Lefèvre Int. J. Dev. Biol. (1999) 43: 839-842

Developmental competence of immature pig oocytes under the influence of EGF, IGF-I, follicular fluid and gonadotropins during IVM-IVF processes.

M J Illera, P L Lorenzo, J C Illera and R M Petters

Int. J. Dev. Biol. (1998) 42: 1169-1172

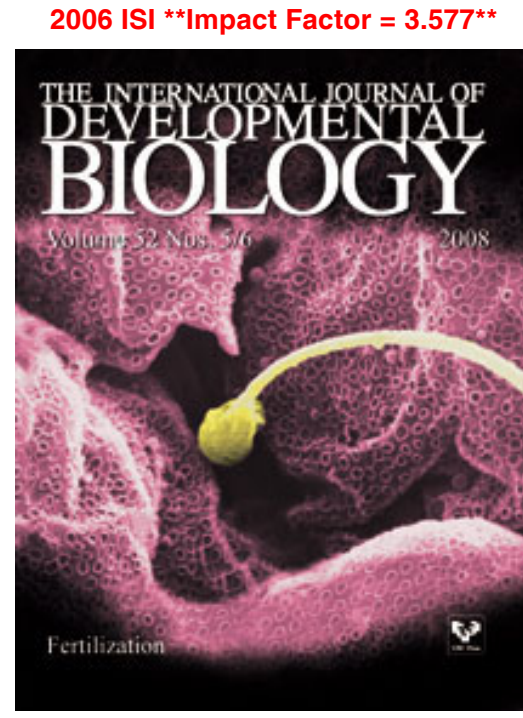

